\title{
ASTRONOMI ISLAM DAN TEORI HELIOCENTRIS NICOLAUS COPERNICUS
}

\author{
Slamet Hambali \\ IAIN Walisongo Semarang \\ e-mail: slamethambaly@yahoo.co.id
}

\begin{abstract}
In the 13th century BC Heliocentric concept presented by the Greek philosopher: Aristarchus. But the theory is still a hypothesis, and contrary to the opinion of Aristoteles. Heliocentric theory has not been able to replace Geocentric one, especially with the emergence of Ptolemy (140 AD), known as a pioneer of the Geocentric theory, who wrote a big book titled Almagest which astronomers have refered for centuries. But after Nicolaus Copernicus wrote a book with the title De Revolutionibus Orbium Coelestium, his published heliocentric theory, and finally It was able to undermine Geocentric theory that has long been established. Qur'an which was revealed long ago before this theory has been presented, has explained the astronomical concept such us motion of earth, that aligned with the Heliocentric theory. In the Qur'an there are some verses of earth, moon and sun, among others: Surat Yūnus: 5, al-Naml: 88, Yāsīn: 38, dan 40, al-Anbiyā': 33, Āli 'Imrān: 190. According to the exegete such Ahmmad Musțafă al-Marāghī in his book Tafsir al-Maräghi, that the Heliocentric theory was the one that inline with the Qur'an, and that the Heliocentric theory is a part of the miracle of the Qur'an.
\end{abstract}

[]

Abad ke-13 SM konsep Heliocentris dikemukakan oleh seorang filosof Yunani: Aristarchus. Namun teori tersebut masih sebatas hipotesa, dan berseberangan dengan pendapat Aristoteles. Teori Heliocentris belum mampu menggantikan teori Geocentris, lebih-lebih dengan munculnya Ptolomeus (tahun $140 \mathrm{M}$ ) yang dikenal sebagai pelopor teori Geocentris, yang menulis buku besarnya berjudul Almagest dan menjadi rujukan para Astronom selama berabad-abad. Namun setelah Nicolaus Copernicus menulis buku dengan judul De Revolutionibus Orbium Coelestium yang mempublikasikan teori Heliocentris, akhirnya teori ini mampu meruntuhkan teori Geocentris yang telah lama mapan. Al-Qur'an yang diwahyukan jauh sebelum teori ini dikemukakan telah menjelaskan konsep astronomi tentang gerak bumi dan selaras dengan teori Heliocentris. Dalam al-Qur'an terdapat ayat-ayat tentang bumi, bulan dan matahari, seperti Surat Yūnus: 5, al-Naml: 88, Yāsīn: 38, dan 40, al-Anbiyā': 33, Âli 'Imrān: 190. Aḥmad Musțafā al-Marāghì dalam Tafsīr al-Marāghī menegaskan bahwa teori Heliocentris-lah yang sesuai dengan al-Qur'an dan lahirnya teori Heliocentris adalah merupakan bagian dari mu'jizat al-Qur'an.

Keywords: heliocentris, geosentris, tafsir, Nicolaus Copernicus

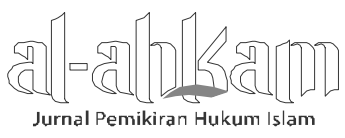




\section{Pendahuluan}

Islam adalah agama samawi terakhir yang diturunkan oleh Allah melalui rasulNya Muhammad SAW dengan kitab suci al-Qur'an, yang lengkap dengan berbagai informasi, yang di antaranya adalah yang menyangkut alam semesta, lebih spesifik lagi adalah yang berhubungan dengan gerak matahari, bumi dan bulan. Al-Qur'an diturunkan oleh Allah SWT kepada Nabi Muhammad SAW melalui malaikat Jibril pada abad ke-7 Masehi, di mana pada saat tersebut ilmu pengetahuan belum berkembang seperti saat sekarang, namun al-Qur'an telah memberikan informasiinformasi penting yang ternyata banyak terbukti pada masa sekarang.

Ketika al-Qur'an diwahyukan kepada Rasulullah SAW pada abad ke-7 M, paham Geosentris masih tertanam kuat dalam wawasan pengetahuan manusia pada masa itu. Bahkan pada era Khulafā' al-Rāshidīn, Bani 'Umayyah, dan Bani 'Abbāsiyyah kepercayaan itu tetap dianut kebanyakan orang. Sehingga, beberapa terminologi ayat al-Qur'an sempat menimbulkan kesulitan yang cukup berat pada ahli-ahli tafsir al-Qur'an zaman itu. Mereka masih terpengaruh bahwa benda-benda langit lain berputar mengelilingi bumi. Misalnya, untuk menerangkan terminologi sab'a samāwāt (tujuh langit) yang diterjemahkan 'tujuh langit', seorang penafsir menjelaskannya sebagai lapisan-lapisan tempat beredarnya benda-benda langit. Menurut tafsir itu, langit pertama merupakan tempat beredarnya bulan. Di langit kedua terdapat A'tharid, 'Merkurius'. Di langit ketiga terdapat Uhra, 'Venus'. Di langit keempat ada matahari. Di langit kelima ada Arikh, 'Mars'. Di langit keenam ada Usytari, 'Yupiter'. Di langit terjauh terdapat Juhal, 'Saturnus'. Beberapa penafsir lain mengambil jalan tengah dengan penuh kehati-hatian menerangkan ayat-ayat "ilmiah" itu. Misalnya, ahli tafsir yang masyhur antara abad X-XI M, al-Ṭabarī, berpendapat bahwa kita harus tutup mulut jika tidak tahu. Barulah beberapa abad kemudian beberapa terminologi al-Qur'an itu dapat dicerna oleh ilmu pengetahuan manusia.

Pada 1543 M akibat revolusi Copernicus (seorang ahli hukum dan ahli astronomi Polandia), timbul banyak ketidaksenangan terutama di kalangan rohaniawan gereja. Penyebabnya adalah pendapat Copernicus yang bertentangan dengan doktrin keagamaannya. Bahkan Martin Luther mengatakan, "Copernicus sudah gila dan teorinya dianggap melawan Injil serta tidak dapat diterima" Nicolaus Copernicus mengemukakan bahwa kerak benda langit akan menjadi lebih sederhana apabila matahari dipandang sebagai pusat jagad raya. Selanjutnya secara tegas ia mengatakan bahwa bukan matahari yang bergerak mengelilingi bumi seperti pandangan Ptolemeus yang dianut selama itu - tetapi justru sebaliknya. 
Bumi bersama benda-benda langit lainnyalah yang bergerak mengelilingi matahari. Copernicus berhasil menurunkan bumi dari kedudukan yang terhormat. Sekarang bumi turun tahta diganti oleh benda yang sangat panas, matahari. Teori ini dikenal sebagai teori Heliocentris. Akhirnya Nicolaus Copernicus (1473-1543 M) adalah seorang filosof berkebangsaan Polandia yang dengan berbekal fakta ilmiah berani memunculkan pandangan (teori) tentang tata surya matahari kita yang sangat kontroversial pada masanya yaitu teori Heliocentris.

Al-Qur'an bukan kitab ensiklopedia detail sains dan teknologi yang memuat berbagai teori. Akan tetapi, al-Qur'an mampu memberikan fenomena-fenomena (yang pada hakikatnya adalah landasan teori) pada manusia, namun yang perlu dikaji adalah bagaimana pandangan astronomi Islam terhadap teori Heliocentris Nicolaus Copernicus

\section{Biografi Nicolaus Copernicus}

Nicolaus Copernicus adalah seorang astronom, matematikawan, dan ekonom berkebangsaaan Polandia, yang mengembangkan teori Heliocentris, ia juga seorang kanon gereja, hakim, dokter, ilmuwan, rahib Katholik, gubernur, pejabat negara, komandan militer, astrolog dan diplomat, ${ }^{1}$ nama sebenaranya adalah Niklas Koppernigk, dalam bahasa latinnya Nicolaus Copernicus dan bahasa Polandianya adalah Mikolaj Kopernik, lahir di kota Torun, tepi sungai Vistula Polandia, pada hari Jum'at (Jawa: Paing), 19 Pebruari 1473 M. dan wafat pada hari Kamis (Jawa: Pon), 24 Mei 1543 M.² Dia berasal dari keluarga berada. Setelah lulus Sekolah Menengah dia melanjutkan kuliah di Universitas Cracow dan mempunyai perhatian yang besar terhadap ilmu perbintangan (astronomi). Pada usia dua puluhan dia berkunjung ke Italia, belajar kedokteran dan hukum di Universitas Bologna dan Padua yang kemudian mendapat gelar Doktor dalam hukum gerejani dari Universitas Ferrara. Nicolaus Copernicus bekerja sebagai staf pegawai Katedral di Frauenburg, selaku ahli hukum gerejani yang profesional, Nicolaus Copernicus tak pernah menjadi astronom profesional, kerja besarnya yang membikin namanya melangit hanyalah berkat kerja sambilan. ${ }^{3}$

\footnotetext{
${ }^{1}$ Nicolaus Copernicus, Father of Modern Astronomy, Blackbirch Inc. 2003.

2Ibid,

${ }^{3}$ Michael H. Hart, Seratus Tokoh yang paling Berpengaruh dalam Sejarah, terj, H. Mahbub Djunaidi, cet. vii (Jakarta: Midas Surya Grafindo, 1986), h. 149.
}

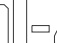

Jurnal Pemikiran Hukum Islam 
Selama berada di Italia, Nicolas Copernicus sudah berkenalan dengan ide-ide Filosof Yunani Aristarchus dari Samos abad ke 13 Sebelum Masehi, kemudian dia melakukan pengamatan terhadap bintang-bintang yang dilakukannya dengan cermat selama bertahun-tahun, baru Nicolaus Copernicus menulis sebuah buku besar yang amat kontroversial dengan judul: "De Revolutionibus Orbium Coelestium" melakukan pengamatan bertahun-tahun (tentang revolusi bulatan benda-benda langit). ${ }^{4}$

\section{Teori Heliocentris}

Teori ini beranggapan bahwa matahari adalah merupakan pusat peredaran planet-planet, termasuk di dalamnya adalah bumi, sedangkan bulan adalah mengelilingi bumi yang kemudian bersama-sama bumi berputar mengelilingi matahari. Sedangkan matahari hanyalah berputar mengelilingi sumbunya saja. Saat ini diketahui bahwa planet-planet dalam tata surya matahari kita jumlahnya ada sembilan, yakni: Merkurius, Venus, Bumi, Mars, Jupiter, Saternus, Uranus, Neptunus dan Pluto, yang kesemuanya berputar mengelilingi matahari. Untuk yang terakhir yakni Pluto, diperselisihkan apakah termasuk planet dalam tata surya matahari kita atau bukan.

Nicolaus Copernicus sebenarnya bukanlah orang pertama yang memunculkan teori Heliocentris, sebelumnya pada abad ke-13 sebelum Masehi (SM) sudah ada Filosof Yunani yang bernama Aristarchus ${ }^{5}$ yang mengutarakan bahwa bumi dan planet-planet berputar mengelilingi matahari, namun ketika itu Aristarchus baru sebatas hipotesa, belum dituangkan dalam bentuk karya tulis, apalagi pada saat itu pendapat Aristarchus tidak sejalan dengan pendapat Aristotels (384 SM-322 SM), sehingga teori Heliocentris Aristarchus tersisihkan oleh teori Geocentris yang menganggap bumi menjadi pusat perputaran bintang-bintang, planet-planet termasuk di dalamnya adalah matahari dan bulan, lebih-lebih dengan munculnya Ptolomeus (tahun 140 M) ${ }^{6}$ yang dikenal sebagai pelopor teori Geocentris, dengan karya tulis buku besarnya berjudul "Almagest" yang dijadikan rujukan para Astronom selama berabad-abad.

\section{${ }^{4}$ Ibid. \\ 5lbid.}

${ }^{6}$ Harold H. Titus, etal., Living Issues in Philosophy, terj. Prof. Dr. H.M. Rosyidi "Persoalan-Persoalan Filsafat" Cet. I (Jakarta: Midas Surya Grafindo, 1984), h. 273. Lihat juga KH. Zubayr Umar al-Jaylanī, alKhulāṣah al-Wafiyyah fi' '-Falaq bi Jadwāl al-Lughatimiyyah (Kudus: Menara Kudus, t.th.), h. 21. 
Karya besar Nicolaus Copernicus yang berjudul "De Revolutionibus Orbium Coelestium" (Tentang Revolusi Bulatan Benda-Benda Langit) yang melukiskan teorinya secara terperinci dan mengedepankan pembuktian-pembuktiannya7, pada saat itu mendapat tantangan keras dari banyak kalangan, di antaranya kaum Lutheran yang merupakan pihak pertama menyebut buku De Revolutionibus Orbium Coelestium itu "tidak masuk akal"8. Gereja Katholik, meski pada mulanya tidak menyatakan kecaman, telah memutuskan bahwa buku De Revolutionibus Orbium Coelestium itu bertentangan dengan doktrin-doktrin resminya dan pada tahun 1616 M. mencantumkan karya Nicolaus Copernicus ke dalam buku-buku terlarang, kemudian dicabut dari daftar terlarang baru pada tahun $1828 \mathrm{M} .{ }^{9}$

Teori Heliocentris Nicolaus Copernicus ini juga mendapat perhatian besar dari para filosof sesudahnya. Setelah melakukan pengamatan dan penelitian yang panjang dan mendalam, mereka membenarkan, mendukung dan menyempurnakan teori Heliocentrisnya Nicolas Copernicus tersebut. Mereka di antaranya adalah Isaac Newton (1642-1727 M) ${ }^{10}$, Galileo Galilei (1564-1642 M) ${ }^{11}$ dan Johannes Kepler (1571-1630 M). ${ }^{12}$ Nicolaus Copernicus disanjung oleh banyak orang dan diberi julukan sebagai Bapak Astronomi Modern, bahkan seorang astrofisikawan Owen Gingerich menyatakan bahwa, "Copernicus-lah yang dengan karyanya memperlihatkan kepada kita bagaimana rapuhnya konsep ilmiah yang sudah diterima untuk waktu yang lama". Melalui pengamatan, penelitian, dan matematika, Copernicus menjungkirbalikkan konsep ilmiah dan agama yang berurat berakar tetapi keliru. Dalam pemikiran manusia, ia juga "menghentikan matahari dan menggerakkan bumi.

\section{Ayat-ayat al-Qur'an tentang Matahari, Bumi dan Bulan}

Al-Qur'an sebagai wahyu Allah yang bersumber langsung dari Allah telah memberikan informasi-informasi tentang alam semesta, khususnya yang berhubungan dengan matahari, bulan dan bumi. Ada 20 ayat yang menyebut kata

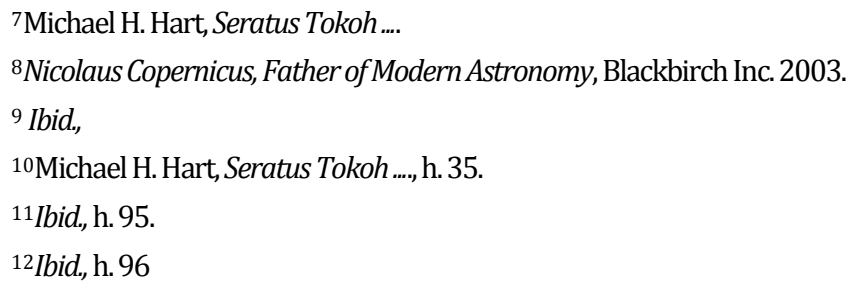


matahari, dan ada 463 ayat yang menyebut kata bumi serta ada 5 ayat yang menyebut kata bulan. Belum lagi ayat yang menjelaskan tentang langit, pergantian siang dan malam, serta ayat yang menyebut tentang bintang-bintang.

Terkait dengan teori Heliocentris, ada beberapa ayat yang menjelaskan tentang gerak matahari, bulan dan bumi, yaitu surat Yūnus: 5, surat Yāsīn: 38, dan surat al-Naml: 88. Beberapa ayat tersebut adalah:

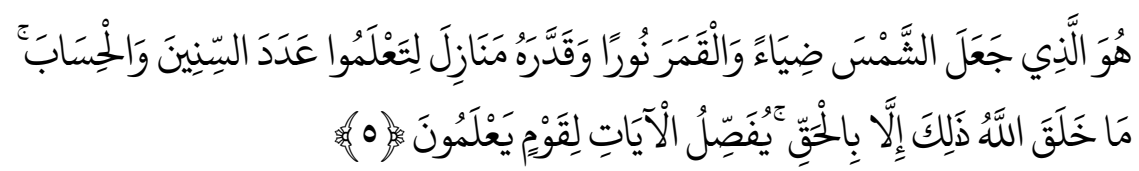

"Dialah yang menjadikan matahari bersinar dan bulan bercahaya dan ditetapkan-Nya manzilah-manzilah (tempat-tempat) bagi perjalanan bulan itu, supaya kamu mengetahui bilangan tahun dan perhitungan (waktu). Allah tidak menciptakan yang demikian itu melainkan dengan hak. Dia menjelaskan tanda-tanda (kebesaran-Nya) kepada orang-orang yang mengetahui."13

Dalam ayat ini Allah menyebut dua benda langit yaitu matahari dan bulan, kemudian Allah menjelaskan adanya ketetapan Allah tentang tempat-tempat perjalanan bulan (secara hakiki bulan beredar mengelilingi bumi dalam satu bulan sinodis rata-rata ditempuh selama 29 hari 12 jam 44 menit 2,8 detik) dan, tidak ada penjelasan tentang perjalanan matahari (apabila diambil mafhūm mukhālafahnya, berarti secara hakiki matahari tidak beredar mengelilingi bumi).

Secara khusus Allah menjelaskan perjalanan matahari dalam surat Yāsīn ayat 38:

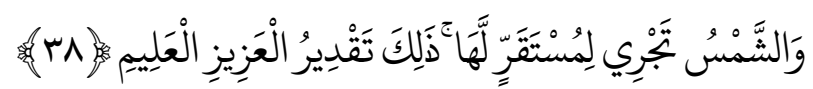

"Dan matahari berjalan di tempat peredarannya. Demikianlah ketetapan yang Maha Perkasa lagi Maha Mengetahui."14

Dalam penjelasan mufradat kata "li mustaqarrin" (لمستقز) al-Marāghī menafsirkannya "Di sekitar tempat tinggal matahari. Al-Marāghī mengatakan "Sungguh mengagumkan, wahai pembaca al-Qur'an al-Karim yang budiman. Kenapakah al-Qur'an itu ternyata telah menetapkan sesuatu yang kemudian ditunjukkan kebenarannya oleh penemuan sekarang dan membantah pendapat-pendapat yang

${ }^{13}$ QS. Yūnus: 5

${ }^{14}$ QS. Yāsīn: 38 
telah tersebut di masa turunnya al-Qur'an di kalangan para ahli falak dari Yunani, India maupun Cina."15

Al-Al-Marāgh pernah menemui dan meminta penjelasan kepada Abdul Hamid Samahah ${ }^{16}$, pimpinan teropong bintang di Mesir yang terletak di Hulwan tentang hal-hal yang telah menjadi ketetapan para ahli falak sekarang, berkaitan dengan teori-teori yang terkandung pada ayat-ayat al-Qur'an. Kemudian Abdul Hamid menulis kepada al-Al-Marāgh sebagai berikut:

\section{Bukti Pertama: Pergantian Siang dan Malam}

Di antara bukti-bukti kekuasaan Allah dengan ciptaan-Nya yang indah ialah adanya pergantian, yakni senantiasa terjadinya pergantian siang dan malam. Hal ini telah disebutkan berkali-kali dalam al-Qur'an al-Karim ${ }^{17}$, karena mengingat gejala astronomi ini sangat penting bagi kehidupan umat manusia maupun makhluk-makhluk lainnya yang tinggal di atas bumi.

Ayat Allah ini termasuk hal yang patut dipikirkan agar dapat dijadikan sebagai bukti atas kebesaran Penciptanya. Malam dipilah dari siang dan siangpun dipilah dari malam. Sebagai hasil dari perputaran bumi mengelilingi sumbunya dari barat ke timur yang disebut gerak rotasi bumi, maka muncul matahari pada ufuk bagian timur dan terbenam pada ufuk bagian barat dengan sangat teratur dan indah.

\section{Bukti Kedua: Gerak Hakiki Matahari}

Selain matahari secara lahiriyah terlihat melakukan peredaran tahunan di tengah-tengah masyarakat bintang-bintang, sebagai akibat dari beredarnya bumi mengelilingi matahari sekali dalam setahun yang disebut gerak revolusi bumi, maka terbukti pula oleh para ahli akhir-akhir ini, bahwa matahari itu juga mempunyai gerakan lain yang hakiki: pertama, beredarnya matahari pada porosnya 1 kali pada tiap kira-kira 26 hari. Hal ini ditunjukkan oleh peneropongan terhadap noda-noda matahari, yaitu bintik-bintik hitam yang nampak pada permukaannya

\footnotetext{
${ }^{15}$ Ahmad Mustafā al-Marāghī, Tafsīi al-Marāghī, Juz 23, Terj. Anwar Rasyidi, et al., "Tafsir alMaraghiy" (Semarang: Toha Putra, 1980), h. 9.

16Muhammad Shaleh Abdul Aziz al-Ujayrī: Salah seorang ahli astronomi Islam, dilahirkan di Kuwait pada tahun 1921 M/1340 H. Al-Ujayrī dianggap sebagai tokoh perancang Kalender Islam Kuwait. Lihat dalam http://museumastronomi.com/tag/muhammad-shaleh-abdul-aziz-al-ujairy/ diakses pada 5 Maret 2013.

${ }^{17}$ QS. al-Baqarah: 164, Āli 'Imrān: 190, Yūnus: 6.

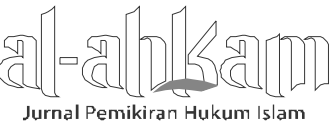


dari masa ke masa, yang ternyata tempat-tempatnya tidak menetap di permukaan matahari, dan menempuh jarak antara dua bulatan matahari dalam tempo 13 hari lamanya.

Kedua, peredaran matahari (dengan segala benda-benda angkasa yang menjadi pengikutnya, yaitu planet-planet dan dengan bulannya masing-masing) mengelilingi pusat alam semesta (sistem bintang) dengan kecepatan kira-kira 200 mil perdetik. Jadi matahari adalah salah satu di antara jutaan bintang yang membentuk alam semesta ini, dan yang terbukti bahwa alam semesta atau sistem bintang itu beredar mengelilingi pusatnya. Dan oleh karena matahari itu ternyata tidak tetap pada pusatnya, maka matahari itu mempunyai gerakan berkeliling.

Adapun yang menjadi pemahaman para ahli ilmu pasti tentang kata مستقر dari suatu tubuh yang melakukan gerakan berkeliling ialah, bahwa kata-kata itu berarti poros tetap dimana gerakan berputar berpusat padanya. Atau berarti pusat lingkaran dari gerakan ini. Dengan arti pertama, maka مستقر berarti garis yang terentang antara dua kutub matahari. Sedang dalam arti yang kedua, مستقر berarti pusat dari sistem bintang selurunya, di mana seluruh bintang-bintang beredar mengelilingi matahari.

\section{Bukti Ketiga: Gerak Semu matahari}

Sebagaimana telah dikatakan, bahwa matahari itu beredar mengelilingi bumi dalam gerakan lahiriyah yang ditimbulkan dari beredarnya bumi mengelilingi matahari. Gerakan lahiriyah seperti seperti yang dirasakan penumpang kereta api ketika ia melihat pohon-pohon, tiang telepon dan desa-desa tampak bergerak tanpa ia merasakan gerakannya sendiri, karena ia berada di dalam kereta api.

Demikianlah kiranya gerakan matahari sebagai akibat dari beredarnya bumi mengelilingi matahari di tengah bintang-bintang lainnya pada garis edar yang sangat luas dengan garis tengah 93 juta mil. Bumi beredar mengelilingi matahari satu kali putaran penuh dalam masa satu tahun. Gerakan seperti ini ditunjukkan oleh berpindahnya matahari di tengah buruj dengan standar satu buruj pada setiap bulan, atau satu derajat setiap hari.18

Sedangkan mengenai gerak bumi, sebagaimana dijelaskan dalam surat alNaml: 88:

\footnotetext{
${ }^{18}$ Aḥmad Musțafāal-Marāghī, Tafsīr al-Marāghī, h. 8-16.
} 


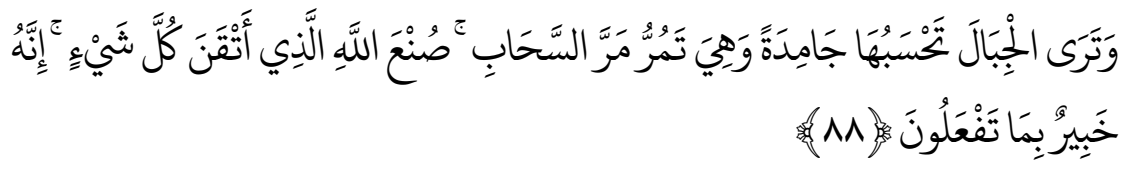

"Dan kamu lihat gunung-gunung itu, kamu sangka dia tetap di tempatnya, padahal ia berjalan sebagai jalannya awan. (Begitulah) perbuatan Allah yang membuat dengan kokoh tiap-tiap sesuatu; sesungguhnya Allah Maha Mengetahui apa yang kamu kerjakan."19

Gunung adalah bagian dari bumi, sehingga kalau dikatakan gunung itu berjalan sebagai jalannya awan, maka hal ini menandakan bahwa bumi ini berjalan sebagai jalannya awan. Awan dalam hal ini tentu tidak pas jika diberi makna hakiki yakni awan yang menjadi hujan. Akan sesuai dengan perkembangan sains modern jika diberi makna majazi, yakni awan dimaknai gugusan bintang-bintang di langit pada saat malam hari ketika langit cerah yang tidak ada hujan dan tidak ada mendung terlihat bintang-bintang bagaikan awan. Dalam ilmu astronomi disebutkan bahwa bumi mempunya empat macam gerak, yaitu rotasi, revolusi, presesi dan nutasi. ${ }^{20}$

Gerak rotasi yang ditempuh selama 23 jam 56 menit 4 detik (1 hari sideris) atau 24 jam (1 hari sinodis), yakni gerak bumi mengelilingi poros yang mempunyai dampak terjadinya pergantian siang dan malam serta semua benda langit atau bintang-bintang terlihat mengelilingi bumi dalam waktu 24 jam betapapun jauhnya. Kedua, gerak revolusi, yaitu gerak bumi mengelilingi matahari yang ditempuh selama 365 hari 5 jam 48 menit 45,2 detik, yang mempunyai dampak matahari selalu bergerak ke utara dan ke selatan sejauh $23^{\circ} 26^{\prime} 26^{\prime \prime}$ dari khatulistiwa/equator langit sebagai akibat dari bumi berputar mengelilingi matahari dalam posisi khatulistiwa/equator bumi senantiasa membentuk $23^{\circ} 26^{\prime}$ 26".

Pada tanggal 21 maret matahari terlihat melintasi daerah khatulistiwa, sehingga semua wilayah permukaan bumi dari kutub selatan sampai kutub utara dapat melihat matahari. Di belahan kutub selatan matahari dalam posisi setengah lingkaran, setengah lingkaran matahari sudah terbenam dan malam hari akan berlangsung selama 6 bulan, Sedangkan untuk kutub utara matahari setengah lingkaran sudah terbit dan siang hari akan berlangsung selama 6 bulan. Sementara

\footnotetext{
${ }^{19}$ QS. al-Naml: 88.

${ }^{20}$ Slamet Hambali, Pengantar Ilmu Falak: Menyimak Proses Pembentukan Alam Semesta Jawa Timur: Bismillah Publisher, 2012), h. 75.
} 
daerah sub tropis bagian utara 21 maret adalah merupakan awal dari musim semi, sebaliknya untuk subtropis belahan selatan 21 maret adalah awal dari musim gugur. Pada saat itu bisa dikatakan di seluruh permukaan bumi perbandingan siang dan malam adalah seimbang, yakni siang 12 jam dan malam 12 jam.

Tanggal 21 Juni matahari terlihat melintasi daerah garis balik utara sejauh $23^{\circ}$ 26' 26" dari khatulistiwa/equator langit. Saat itu merupakan awal musim panas bagi bagi daerah sub tropis utara, awal musim dingin bagi daerah sub tropis selatan. Untuk daerah sub tropis utara siang lebih panjang dari pada malam, bahkan seperti kota Murmansk Rusia yang lintang $(\phi)$ nya $=+68^{0} 58^{\prime}(\mathrm{LU})$ matahari tidak pernah terbenam yang sudah berlangsung selama 1 bulan dan masih akan berlangsung selama 1 bulan lagi.

Tanggal 23 September matahari kembali lagi terlihat melintasi daerah khatulistiwa/equator langit yang berarti untuk seluruh permukaan bumi perbandingan siang dan malam adalah seimbang yakni, 12 siang dan 12 jam malam, walaupun untuk kutub utara matahari terlihat hanya setengah lingkarannya saja yang setengah lingkaran sudah terbenam, juga untuk kutub selatan matahari hanya terlihat setengahnya saja, yang setengah lingkarannya belum terbit (masih di bawah ufuk). Pada saat itu untuk sub tropis utara adalah merupakan awal musim gugur, sedangkan untuk daerah sub tropis selatan adalah saat awal musim semi.

Tanggal 22 Desember matahari terlihat melintasi daerah garis balik selatan sejauh $23^{\circ} 26^{\prime} 26^{\prime \prime}$ dari khatulistiwa/equator langit. Saat itu merupakan awal musim panas bagi daerah sub tropis selatan, awal musim dingin bagi daerah sub tropis utara. Untuk daerah sub tropis selatan siang lebih panjang dari pada malam, bahkan untuk daerah di mana lintang dan deklinasi matahari jumlahnya $90^{\circ}$, maka daerah itu matahari tidak akan pernah terbenam.

Gerak presesi, ditempuh hampir selama 26.000 (dua puluh enam ribu tahun), yaitu gerak sumbu bumi bergoyang membentuk kerucut, yang berdampak berpindahnya titik aries (titik pertemuan antara lingkaran ekliptika dengan lingkaran equator langit) ke arah barat.

Gerak nutasi, ditempuh selama 19 tahun, yaitu gerak goyang sumbu bumi di dalam berpresesi, yang berdampak selalu berpindah-pindahnya kutub magnet bumi yang, terkadang berimpit dengan kutub bumi, pada saat yang lain tidak berimpit, suatu saat kutub magnet berimpit dengan bujur Semarang dan pada saat yang lain tidak berimpit dengan bujur Semarang.

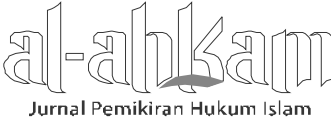




\section{Kesimpulan}

Teori Heliocentris Nicolas Copernicus telah membuktikan kebenaran ilmu pengetahuan yang dibawa oleh al-Qur'an. Ayat-ayat al-Qur'an secara tegas menunjukkan bahwa tidak ada pertentangan dengan ilmu pengetahuan modern, khususnya yang berkaitan dengan ilmu astronomi, walaupun al-Qur'an diturunkan jauh sebelumnya, yaitu pada abad ke-7 Masehi. Argumentasi al-Qur'an tentang kebenaran astronomi Islam juga ditegaskan oleh Aḥmad Muștafă al-Marāghĩ dalam kitab tafsirnya Tafsiir al-Marāghī ketika menafsirkan surat Yasin: 38. Melalui analisis terhadap tiga bukti peristiwa astronomis, yaitu: pergantian siang dan malam, gerak hakiki matahari, dan gerak semu matahari, al-Marāghī sampai pada kesimpulan bahwa ada kesesuaian yang sangat presisi antara teori astronomi Islam yang diajarkan oleh al-Qur'an dengan teori astronomi modern. Kesesuaian ayatayat al-Qur'an dengan sains modern menurut al-Marāghī juga merupakan bagian dari mu'jizat al-Qur'an yang benar-benar dapat dibuktikan.[a]

\section{DAFTAR PUSTAKA}

Azhari, Susiknan, Ensiklopedi Hisab Rukyat, Yogyakarta: Pustaka Pelajar, 2005.

Azhari. Susikan, Ilmu Falak, Perjumpaan Khazanah dan Sains Modern, Cet. II, Yogyakarta: Suara Muhammadiyah, 2007.

Badan Hisab \& Rukyah Departemen Agama, Almanak Hisab Rukyat, Jakarta, Proyek Pembinaan Badan Peradilan Agama Islam, 1981.

Hambali, Slamet, Pengantar Ilmu Falak: Menyimak Proses Pembentukan Alam Semesta, Jawa Timur: Bismillah Publisher, 2012.

Hart, Michael H., The 100, a Ranking of the Most Influential Persons in History, terj, $\mathrm{H}$. Mahbub Djunaidi "Seratus Tokoh yang paling berpengaruh dalam sejarah", Cet. VIII, Jakarta: Midas Surya Grafindo, 1986.

al-Jaylanī, K.H. Zubayr 'Umar, al-Khulāșah al-Wafiyyah fi 'l-Falaq bi Jadwāl alLughatimiyyah, Kudus: Menara Kudus, t.th.

Khozin. Muhyiddin, Ilmu Falak dalam Teori dan Praktek, Yogyakarta: Buana Pustaka, 2004.

al-Marāghī, Ahmad Muștafā, Tafsìr al-Marāghī, Mesir: Muștafāa al-Bābī 'l-Ḥalabī, 1974.

al-Marāghī, Aḥmad Muștafā, Tafsīr al-Marāghī , Juz 23, terj. Anwar Rasyidi, et.al,, "Tafsir al-Maraghiy" Semarang: Tohaputra, 1980.

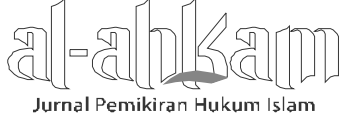


Slamet Hambali

Nicolaus Copernicus, Father of Modern Astronomy, Blackbirch Inc. 2003.

Oliver Montenbruck Thomas Pfleger, 1994, Astronomi on the Personal Computer, Cet. II. Berlin: Spinger-Verlag.

Orderay, Richard, 1971, Earth Scienc, Reinhold: Van Nostrand.

Titus, Harold H., et.al., Living Issues in Philosophy, terj. Prof. Dr. H.M. Rosyidi "Persoalan-Persoalan Filsafat" Cet. I, Jakarta: Midas Surya Grafindo, 1984.

Saadoeddin, Djambek, AlmanakJamiliyah, Jakarta: Tintamas, 1953.

Shihab, M. Quraish, Tafsir al-Mishbah, Jakarta: Lentera Hati, 2002.

236 || Volume 23, No. 2, Oktober 2013 Jurnal Pemikiran Hukum Islam 